\title{
LA DEMOCRACIA Y SUS DIVERGENCIAS: PROBLEMAS Y ENFOQUES
}

JUAN RUSSO

Juan Russo, es miembro del Sistema Nacional de Investigadores, CONACYT, y Profesor de la Universidad de Guanajuato, México, con sede en la División de Ciencias Sociales y Humanidades.

Campus León, Bv. Puente Milenio 1001; Fracción del Predio San Carlos; C.P. 37670; León, Guanajuato, México.

e-mail: juan_russo@hotmail.com

\section{Resumen}

Los estudios sobre divergencia democrática (divergencias entre ideales y resultados del orden político) son tan antiguos como el concepto mismo de democracia. Estos estudios han seguido dos rutas: una perspectiva vertical, que privilegia las relaciones entre gobernantes y ciudadanos, y una perspectiva horizontal, que atiende a la calidad de las relaciones sociales y de los vínculos comunitarios. Los enfoques verticales incluyen, someramente, los estudios sobre el Estado y las instituciones que regulan las relaciones entre autoridades, organizaciones y ciudadanos; mientras los enfoques horizontales a los estudios comunitarios, relacionales y culturales. Ambos enfoques se han propuesto explicar por qué las democracias tienen problemas de rendimiento. En este trabajo se hace un repaso por las diversas perspectivas agrupadas en estos dos grandes enfoques sobre las democracias contemporáneas. Por último, se plantean interrogantes que combinan ambas perspectivas, sobre la democracia en México.

El autor agradece al Centro de Investigación y Docencia Económica, CIDE, por el apoyo para la realización de este trabajo.

\section{Summary}

The studies regarding democratic divergence (divergence among ideals and political outcomes) are as ancient as the concept of democracy itself. These studies have followed two paths: a vertical perspective, which privileges the relationship amongst government and citizens, and a horizontal perspective, that attend the quality of social relationships and community bonds. A vertical approach, include studies concerning the State and the institutions that govern relations between authorities, organizations and citizens; while the horizontal approach focuses on the community, relational and cultural studies. Both approaches have been proposed to explain why democracies have performance problems. This paper reviews, the various perspectives grouped into these two major approaches on contemporary democracies. Ultimately, questions are raised combining both perspectives on democracy in Mexico. 